\title{
RACIONALIDADE E EXCLUSÃO NA TEORIA POLÍTICO-CONSTITUCIONAL RAWLSIANA
}

RATIONALITY AND EXCLUSION IN RAWLSIAN POLITICAL-CONSTITUTIONAL THEORY RACIONALIDAD Y EXCLUSIÓN EN LA TEORÍA POLÍTICO CONSTITUCIONAL DE JOHN RAWLS

Vera Lucia da Silva ${ }^{1}$

Resumo: A pretensão de autossustentabilidade da concepção política de justiça equitativa rawlsiana é seu diferencial em relação às demais teorias em filosofia política. Essa independência da justiça equitativa em relação às doutrinas morais permite vislumbrar um arranjo institucional estável nas sociedades democráticas, apesar do pluralismo de crenças e valores. O objetivo desse artigo é verificar os limites da independência da justiça equitativa em relação às doutrinas morais. Para tanto, procedeuse à leitura das principais obras de John Rawls, orientada pela metodologia dedutiva. Dessa aproximação teórica, verificou-se que a concepção de pessoa racional compromete a justiça rawlsiana com uma doutrina metafísica de pessoa. Tal doutrina considera ir-

1 Doutora em Direito, Política e Sociedade pela Universidade Federal de Santa Catarina, com período de investigação (Sanduíche) na Vanderbilt University (TN/EUA), financiada pelo CNPq. Mestre em Filosofia do Direito pela mesma instituição. Especialista em Direito Penal e Processual Penal pela Escola do Ministério Público de Santa Catarina. Assistente Jurídica na Procuradoria Geral do Estado de Santa Catarina. E-mail: veralucia@pge.sc.gov.br. 
racional determinados projetos de bem, como o do jogador. Nesse sentido, a concepção política de justiça pode ser considerada como uma doutrina moral abrangente, que determina e exclui modos de vida a partir da concepção de racionalidade. Tal exclusão revela que a teoria política liberal rawlsiana não conseguiu superar os limites do liberalismo moderno, dependente que é ainda de valores morais bastante determinados. O problema passa a ser a eliminação dos elementos perturbadores da estabilidade política, o que limita a possibilidade dos conflitos. Assim, a sociedade bem-ordenada rawlsiana seria limitada como projeto democrático, vez que sustentada por valores morais abrangentes. Tal fato contraria diretamente os próprios propósitos de Rawls declarados em Uma Teoria da Justiça.

Palavras-chave: racionalidade, concepção política de justiça, doutrina metafísica de pessoa, doutrina moral abrangente, jogador.

Abstract: The pretension of self-sustainability of the Rawlsian political concept of justice is what differentiates it from other theories in political philosophy. Its independence in relation to comprehensive moral doctrines allows a stable institutional arrangement in democratic societies, despite the pluralism of beliefs and values. The purpose of this article is to verify the real limits of this independence in relation to moral doctrines. This requires reading the main works of John Rawls, guided by the deductive methodology. This theoretical approach showed that the concept of rational person compromises Rawlsian with a metaphysical doctrine of person. This doctrine holds irrational certain projects of good, such as gambling, for example. Thus, the political concept of justice can be regarded as a comprehensive moral doctrine, which determines and excludes ways of life from the concept of rationality.

Keywords: rationality, political concept of justice, metaphysical doctrine of person, comprehensive moral doctrine, gambler.

Resumen: La pretensión de autosostenibilidad de la concepción política de justicia equitativa de Rawls es su diferencial en relación a las demás teorías en filosofía política. Esa independencia de la justicia equitativa en relación a las doctrinas morales permite vislumbrar un arreglo institucional estable en las sociedades democráticas, a pesar del pluralismo de creencias y valores. El objetivo de este artículo es verificar los límites de la independencia de la justicia equitativa en relación a las doctrinas morales. 
Para ello se procedió a la lectura de las principales obras de John Rawls, orientada por la metodología deductiva. A partir de esa aproximación teórica se verificó que la concepción de persona racional compromete la justicia rawlsiana con una doctrina metafísica de persona. Tal doctrina considera irracionales determinados proyectos de bien, como el del jugador. En ese sentido, la concepción política de justicia puede ser considerada como una doctrina moral abarcadora, que determina y excluye modos de vida a partir de la concepción de racionalidad. Tal exclusión revela que la teoría política liberal de Rawls no logró superar los límites del liberalismo moderno, dependiente todavía de valores morales bastante determinados. El problema pasa a ser la eliminación de los elementos perturbadores de la estabilidad política, lo que limita la posibilidad de los conflictos. Así, la sociedad bien ordenada de Rawls estaría limitada como proyecto democrático, puesto que sustentada por valores morales abarcadores. Tal hecho contradice directamente los propios propósitos de Rawls declarados en Teoría de la Justicia.

Palabras clave: Racionalidad; Concepción política de justicia; Doctrina metafísica de persona; Doctrina moral abarcadora; Jugador.

INTRODUÇÃO

autossustentabilidade da justiça equitativa de John Rawls é um dos
argumentos que distingue sua teoria dajustiça de noções abrangentes
- para o autor, essa é a grande vantagem de sua proposta. Em suma, o que diferencia a formulação política presente em Uma Teoria da Justiça (UTJ) de outras obras é a possibilidade de seus princípios serem aceitos por qualquer sujeito, independentemente de razões morais. É suficiente, no plano subjetivo, a existência de sujeitos racionais e razoáveis para a formulação de princípios de justiça tal como os enunciados pela justiça equitativa.

O presente artigo problematiza justamente a autossustentabilidade da teoria da justiça formulada por John Rawls. O objetivo foi reconstruir a dependência 
dessa teoria da justiça com doutrinas morais particulares, o que a compromete com ideários excludentes. Para verificar tal hipótese, foram lidas as principais obras de John Rawls, como UTJ e O liberalismo político (LP). Foi também formulado um arquétipo, ou tipo humano-moral específico, o "jogador", a partir da leitura da obra de mesmo nome, de Fiódor Dostoiévski. Com esse arquétipo, pretendese dedutivamente explicitar a hipótese de comprometimento moral da justiça equitativa com ideários políticos específicos, o que atinge o núcleo central de sua autossustentabilidade.

O esforço teórico do autor de UTJ foi construir uma teoria de justiça universal, cujos princípios pudessem ser conjuntamente formulados por membros de qualquer democracia constitucional, baseada em liberdades básicas (expressão, pensamento e movimento). Os membros dessa democracia professam diversas concepções de bem e projetos de vida. São livres para a determinação de suas concepções pessoais. Apesar desse fato do pluralismo, sujeitos com diversas concepções morais de bem conseguem estabelecer princípios de justiça comuns para o funcionamento das instituições. Esses princípios são os fundamentos da justiça equitativa rawlsiana.

Aceito o fato do pluralismo, cada membro da sociedade deve ser respeitado em suas liberdades básicas e estas devem ser igualmente distribuídas. Cada membro livre e igualmente considerado aceitará os princípios de justiça equitativos, conforme definidos em UTJ. Essa aceitação ocorre porque os princípios de justiça não violam as liberdades fundamentais e tampouco sua distribuição equitativa ao contrário, as garantem.

A formulação desses princípios de justiça equitativos depende da condição de liberdade e de igual consideração dos membros da sociedade. Sujeitos livres e igualmente considerados estão aptos à formulação de princípios públicos que resguardem essa condição. Por essa característica é que Rawls afirma o caráter político de sua teoria da justiça: tanto porque os princípios de justiça são publicamente formulados, como porque tais princípios têm por objeto o 
funcionamento das instituições básicas da sociedade. Com esses princípios, as liberdades fundamentais dos membros seriam garantidas apesar do fato do pluralismo.

Além do mais, a justiça como equidade é independente de qualquer doutrina específica que direcione a vida individual. Todo e qualquer membro de uma sociedade livre e igualmente considerado poderá, sem qualquer prejuízo para seu sistema pessoal de fé e crenças, concordar com os princípios de justiça de UTJ. Por isso, a formulação dos princípios de justiça não pode depender de qualquer doutrina moral abrangente (entendidas como sistemas morais que exerçam poder normativo sobre os mais diversos e amplos aspectos da vida dos sujeitos). Assim, os princípios de justiça seriam aceitáveis por quaisquer membros da sociedade, sem depender de coerções morais específicas.

Apesar disso, a formulação da justiça equitativa é sensível ao argumento das exigências não públicas sobre os sujeitos. Isso porque membros livres e igualmente considerados poderiam estabelecer outros princípios de justiça não equitativos. Por isso, a escolha dos princípios de justiça depende não somente de sua condição de liberdade e igualdade, mas também de capacidades morais dos membros da sociedade. Assim, a justiça equitativa é diretamente derivada de uma noção pública de pessoa, dotada de capacidades morais políticas. E, no momento de escolha de princípios, a capacidade existente é a racionalidade.

A racionalidade permite que as partes reconheçam princípios que promovam seus objetivos da melhor maneira possível, na tentativa de garantir para si o maior índice de bens primários. Para tanto, é necessário o estabelecimento de princípios de justiça que prevejam a todo e qualquer membro igual oportunidade de realização de seus projetos de vida.

Por isso, os membros da sociedade, no estabelecimento dos princípios de justiça, não devem tentar levar vantagens uns sobre os outros; não devem ser movidos pela inveja ou pela vaidade. O esforço dos membros é somente pelo estabelecimento de princípios de justiça moderados, cujas consequências possam 
ser suportáveis posteriormente. Essa escolha de princípios só pode ser orientada pela racionalidade, cuja expressão é assegurada pelo expediente conhecido como véu de ignorância.

Então, a racionalidade é a capacidade moral que garante a consciência dos membros da necessidade de um bem social para a realização de seus projetos de vida. Nesse sentido, Rawls não permite a participação do sujeito jogador no momento da afirmação dos princípios de justiça. Isso porque o jogo, em Uma Teoria da Justiça, seria atividade motivada pelo desejo de ganhar. Se há esse desejo de ganho, haverá necessariamente um perdedor, desaparecendo a equidade promovida pelos princípios de justiça. E como o cálculo das vantagens sociais proposto para a formulação de princípios de justiça equitativos não pode admitir a existência de uma posição absolutamente prejudicada, a posição do perdedor seria inadmissível. Assim, não há que se pressupor um ganhador. Por isso, o jogador não seria admitido como um formador dos princípios de justiça. A questão é que o jogador não estaria motivado, segundo Rawls, racionalmente. Isso porque seu desejo de ganho o conduziria a termos desequilibrados de cooperação. A termos que inclusive não estaria disposto a se submeter posteriormente, caso seu status fosse de perdedor.

Nesse ponto, duas considerações são necessárias. A primeira, o fato de que o jogador não possa ser considerado um membro racional da sociedade - ou que o jogo seja uma motivação irracional. O problema está na concepção de jogo de Rawls, pela qual o jogador é necessariamente um sujeito que tem por objeto a vitória. O que passa despercebido, no entanto, é que a vitória provém do melhor desempenho e da melhor sorte, segundo obediência às regras do jogo. Não há possibilidade de jogo sem regras, e o jogador é o sujeito que, acatando as regras, submete-se a elas. As regras dos jogos igualam os participantes. O jogo não desequilibra as partes. As regras servem igualmente a todos os membros do jogo, embora o final da partida possa coincidir com a derrota de uma das partes. Mas o fato de resultar em desigualdade de partes não faz da regra do jogo um termo desequilibrado de cooperação social - o jogo é indiferente à ideia de equilíbrio. 
A segunda questão é que a capacidade racional exclui o membro jogador do estabelecimento dos princípios de justiça. Isso comprova a tese de que a justiça como equidade depende diretamente de uma doutrina moral metafísica de pessoa. Tal exclusão ocorre porque a capacidade do racional exige o estabelecimento de termos equitativos de cooperação social, excluindo aqueles que não estejam dispostos ao que se considera como equitativo. Com isso, verifica-se o compromisso da justiça equitativa com uma concepção abrangente de pessoa e, portanto, racionalmente refutável.

A crítica à noção rawlsiana de jogador foi realizada a partir do personagem Aleksiéi Ivânovitch, narrador do romance Um Jogador, de Dostoiévski. A reconstrução literária do jogador é eficiente para demonstrar o compromisso de Rawls com um ideal de pessoa racional moralizante. Consequentemente, a dissolução de um ambiente político livre. Nesse sentido, no liberalismo de Rawls à atividade política é direcionada à boa vida de seus membros ideais, esgotando a atividade política em sua concepção metafísica de pessoa.

\section{DOUTRINAS ABRANGENTES E AUTOSSUSTENTABILIDADE DA JUSTIÇA COMO EQUIDADE - O ESFORÇO POR UMA CONCEPÇÃO POLÍTICA DE JUSTIÇA}

Aautossustentabilidade da teoria dajustiça rawlsiana seria sua grande vantagem sobre outras teorias da justiça. Isso porque confere status de independência da ideia de justiça em relação a doutrinas abrangentes ${ }^{23}$. Essa independência assegura o caráter exclusivamente político da concepção de justiça desenvolvida por Rawls. Por isso, os preceitos da justiça equitativa somente são destinados às instituições políticas, respeitando a liberdade básica de crença e pensamento de cada membro da sociedade.

2 "Embora queiramos que uma concepção política encontre justificação com referência a uma ou mais doutrinas abrangentes, ela não é apresentada como tal nem deriva de uma doutrina desse tipo aplicada à estrutura básica da sociedade, como se essa estrutura fosse simplesmente outro tópico ao qual a doutrina é aplicada." RAWLS, John. O Liberalismo Político. Tradução de Dinah de Abreu Azevedo. 2. ed. São Paulo: Ática, 2000. p. 54-55

3 RAWLS, John. O Liberalismo Político. Tradução de Dinah de Abreu Azevedo. 2. ed. São Paulo: Ática, 2000. p. 54-55. 
Doutrinas abrangentes são aquelas "que se aplicam a um amplo leque de objetos". Orientam condutas evalores em "nossa vida, como um todo"4. As doutrinas podem ser inteiras ou parcialmente abrangentes, a depender da amplitude de seu alcance normativo ${ }^{5}$. O importante é que as doutrinas abrangentes, de qualquer natureza, orientam valores e virtudes não políticos ${ }^{6}$.

Essas doutrinas, por sua abrangência, são "sujeitas a controvérsias"7, especialmente em uma sociedade democrática. Um exemplo de doutrina

4 RAWLS, John. 0 Liberalismo Político. Tradução de Dinah de Abreu Azevedo. 2.ed. São Paulo: Ática, 2000. p. 56.

5 Este ponto da amplitude e da generalidade das doutrinas abrangentes não é claramente especulado por John Rawls. $\mathrm{O}$ argumento sobre a diferença de amplitude entre doutrinas parcial e inteiramente abrangentes é simples e rápido, sem claras alusões à distinção entre ambas. Simplesmente referencia uma diferença entre articulação de valores, em que as doutrinas parcialmente abrangentes seriam "mais frouxas". Mas não é claro seu argumento que tipo de doutrina abrangente poderia ser considerada "mais frouxa" que outra, que tipo de questões normativas separam uma doutrina parcial ou inteiramente abrangente. Essa falta de clareza no tratamento da questão pode trazer complicações para o argumento de que doutrinas filosóficas e religiosas são abrangentes. Isso porque sua própria doutrina, quando determina uma concepção política de pessoa, pode ser considerada também uma moral abrangente (como no caso, o sujeito que aspira por estabelecer termos equitativos de cooperação social.). Isso porque essa capacidade racional de estabelecer termos equitativos de cooperação depende de escolhas não políticas, nos termos de Rawls. A dificuldade está justamente na separação entre o que representa uma decisão pública ou privada. Um exemplo poderia ser o de um médico, que, ocupando uma função pública, exerce objeção de consciência em um caso específico. Imaginemos um médico que se nega a promover um procedimento cirúrgico alegando razões religiosas. Vejamos: a liberdade de culto e de crença é uma das liberdades básicas segundo o pensamento liberal - assim o âmbito do privado é resguardado publicamente. Tão público o quanto é o dever do médico em atender seus pacientes. Entretanto, o médico usa de sua doutrina abrangente para julgar um caso público - como o dever de prestar assistência. Entretanto, a doutrina religiosa alegada pelo médico é tutelada publicamente como uma de suas liberdades. Assim, o público, no resguardo das liberdades básicas, acaba por confundir-se com doutrinas abrangentes. E mais, a definição da abrangência das concepções poderia servir como base de fundamentação para resolver problemas práticos, como o proposto. Em abstrato, parece simples a separação entre as esferas políticas e pessoais, mas nos casos concretos a justiça equitativa não oferece arcabouço suficiente para a resolução de graves conflitos. Esse ponto sobre as doutrinas abrangentes merecia ser elucidado pelo autor.

6 A doutrina "é abrangente quando trata de concepções sobre o que tem valor na vida humana, ideais de caráter pessoal, de amizade, de relações familiares e associativas, assim como muitas outras coisas que devem orientar nossa conduta e, em sua extrema amplitude, nossa vida como um todo." RAWLS, John. O Liberalismo Político. Tradução de Dinah de Abreu Azevedo. 2.ed. São Paulo: Ática, 2000. p. 56. Ou melhor, "Uma concepção é dia geral quando se aplica a uma gama extensa de questões (praticamente a todas); ela é dita abrangente quando compreende as concepções daquilo que tem valor para a existência humana, os ideais referentes à virtude e ao caráter pessoais, ideais que influenciam boa parte da nossa conduta não política (e praticamente toda a nossa existência)". RAWLS, John. Justiça e democracia. Tradução de Irene A Paternot. São Paulo: Martins Fontes, 2000. p. 295.

7 "Em resumo, a ideia é que, numa democracia constitucional, a concepção pública da justiça deveria ser, tanto quanto possível, independente de doutrinas religiosas ou filosóficas sujeitas a controvérsias. É por isso que, na formulação de tal concepção, devemos aplicar o princípio de tolerância à própria filosofia: a concepção pública da justiça deve ser política e não metafísica." RAWLS, John. Justiça e democracia. Tradução de Irene A Paternot. São Paulo: Martins Fontes, 2000. p. 202. 
abrangente proposto por Rawls é o utilitarismo. Segundo o autor, o princípio da utilidade é válido (ou pretende ser) para todo o tipo de objeto, seja na esfera pública ou nos juízos privados dos indivíduos. Assim, o utilitarismo é considerado por Rawls uma doutrina moral abrangente. Por sua generalidade de aplicação, o utilitarismo acarreta sua própria refutação - os indivíduos morais não são racionalmente obrigados a aceitar a utilidade como máxima de julgamento moral e das decisões políticas ${ }^{8}$.

A questão é que as doutrinas abrangentes são refutáveis, especialmente em uma sociedade democrática cujo fundamento está na garantia das liberdades básicas (como a de crença e pensamento, por exemplo) ${ }^{9}$. Assim, nenhuma das doutrinas morais abrangentes serve como base ao funcionamento das instituições públicas, que compõem a estrutura básica da sociedade ${ }^{10}$. Por isso, é necessária uma concepção política de justiça, que seja independente de qualquer outra doutrina abrangente, ou de quaisquer exigências morais relacionadas a tais doutrinas.

8 Rawls reconstruiu a perspectiva utilitarista clássica. O utilitarismo, segundo essa vertente, parte de um observador imparcial que se converteria em legislador. A partir desse sujeito político, seriam tomadas as decisões públicas. Essas decisões se assemelham à gestão de recursos, pois, por meio de cálculos, chega-se à maximização da satisfação em relação aos bens. O problema dessa visão da justiça política é que sua construção estende "à sociedade o princípio da escolha para um único ser humano, e, depois, fazer a extensão funcionar, juntando todas as pessoas numa só, através dos atos criativos do observador solidário e imparcial." RAWLS, John. Uma teoria da justiça. Tradução de Altamiro Piseta e Lenita M. R. Esteves. São Paulo: 'Martins Fontes, 2000. p. 29-30. Ou seja, o problema está em que o observador imparcial terá um sistema de julgamento de satisfações e vantagens. Mas este sistema não é o válido para todas as pessoas, especialmente em uma sociedade democrática. Isso porque obviamente cada qual tem um sistema de preferências e prioridades diverso. Por isso, para Rawls, "O utilitarismo não leva a sério a diferença entre as pessoas." RAWLS, John. Uma teoria da justiça. Tradução de Altamiro Piseta e Lenita M. R. Esteves. São Paulo: 'Martins Fontes, 2000. p. 30.

9 "As doutrinas religiosas e filosóficas expressam visões de mundo e de nossa vida uns com os outros, individual ou coletivamente, como um todo. Nossos pontos de vista individuais e associativos, afinidades intelectuais e ligações afetivas são diversificados demais, principalmente numa sociedade livre, para que essas doutrinas possam servir como base para um acordo político duradouro e razoável." RAWLS, John. O Liberalismo Político. Tradução de Dinah de Abreu Azevedo. 2.ed. São Paulo: Ática, 2000. p.102. A diante, a ideia de razoabilidade será explanada.

10 "Entende-se por estrutura básica a maneira pela qual as principais instituições sociais se arranjam em um sistema único, pelo qual consignam direitos e deveres fundamentais e estruturam a distribuição de vantagens resultante da cooperação social. A constituição política, as formas de propriedade legalmente admitidas, a organização da economia e a natureza da família, todas, portanto, fazem parte dela." (Idem, ibidem, p. 1 - original de 1977). Esta descrição é ainda em O Liberalismo Político. RAWLS, John. O Liberalismo Político. Tradução de Dinah de Abreu Azevedo. 2. ed. São Paulo: Ática, 2000. p. 309, texto original datado de 1993. 
A formulação de uma teoria da justiça autossustentável exige fundamentação independente de qualquer doutrina abrangente - muito embora tais doutrinas possam constituir o ponto de partida para a aceitação da concepção política de justiça ${ }^{11}$. Entenda-se que a teoria rawlsiana considera que o sujeito possa ser conduzido a aceitar por suas razões morais os preceitos da justiça equitativa. Mas tal fundamentação moral não é necessária à justiça política12, ou ao menos não deve se exigir dos membros da sociedade a aceitação por uma razão moral.

\section{O essencial é considerar que o objeto de uma concepção política de justiça é} orientar o funcionamento das instituições públicas (sociais, políticas e econômicas)

- o que Rawls denominou como estrutura básica da sociedade ${ }^{13}$. Por isso mesmo,

11 "O ponto essencial é que, em matéria de prática política, nenhuma concepção moral geral pode fornecer um fundamento publicamente reconhecido para uma concepção da justiça no quadro de um Estado democrático moderno. (...) De fato, esta deve ter em conta uma diversidade de doutrinas e a pluralidade das concepções do bem que se defrontam e que são efetivamente incomensuráveis entre si, sustentadas pelos membros das sociedades democráticas existentes." (Idem, ibidem, p.204)

12 "Mas um traço distintivo de uma concepção política é o fato de ser apresentada como autossustentável e explanada à parte, ou sem qualquer referência a um contexto tão amplo (quanto o das doutrinas abrangentes). Usando uma expressão em voga, a concepção política é um módulo, uma parte constitutiva essencial que se encaixa em várias doutrinas abrangentes razoáveis subsistentes na sociedade regulada por ela, podendo conquistar o apoio daquelas doutrinas. Isso significa que pode ser apresentada sem que se afirme, saiba ou se arrisque uma conjectura a respeito das doutrinas a que possa pertencer ou de qual delas poderá conquistar apoio. (grifo nosso). (RAWLS, John. O Liberalismo Político. Tradução de Dinah de Abreu Azevedo. 2.ed. São Paulo: Ática, 2000. p. 55)

13 "A primeira característica diz respeito ao objetivo de uma concepção política. Embora tal concepção seja, evidentemente, uma concepção moral, trata-se de uma concepção moral elaborada para um tipo específico de objetivo, qual seja, para instituições políticas, sociais e econômicas. Em particular, ela se aplica ao que chamarei de "estrutura básica" da sociedade, que, para nossos propósitos atuais, suponho seja uma democracia constitucional moderna (uso "democracia constitucional", "regime democrático" e expressões semelhantes como sinônimos, especificando quando não o são). (...) Portanto, o foco inicial de uma concepção política de justiça é a estrutura das instituições básicas e os princípios, critérios e preceitos que se aplicam a ela, bem como a forma pela qual essas normas devem estar expressas no caráter e nas atitudes dos membros da sociedade que realizam seus ideais". (idem, ibidem, p.53-4). Notar com atenção que apesar de política, a concepção de justiça é moral e vincula o comportamento dos indivíduos. Mas nesse ponto, convém diferenciar a abrangência da justiça equitativa - o comportamento orientado é em relação às instituições políticas e não nos limites privados. Assim, a concepção política de justiça serve ao propósito da construção de uma razão pública política. Segundo o próprio Rawls "(...) numa sociedade democrática, a razão pública é a razão de cidadãos iguais que, enquanto corpo coletivo, exercem um poder político final e coercitivo uns sobre os outros ao promulgar leis e emendar sua constituição." (idem, ibidem, 263-4). A consequência dessa concepção de razão pública é que "(...) seus limites não se aplicam a nossas deliberações e reflexões pessoais sobre questões políticas, nem à discussão sobre elas por parte de membros de associações como as igrejas e as universidades, constituindo tudo isso uma parte da vital da cultura de fundo (...) Mas o ideal de razão pública aplica-se aos cidadãos quando atuam na argumentação política no fórum público (...)" (idem, ibidem). 
a concepção política não poderia ser comprometida com qualquer doutrina moral abrangente - assim pode ser aceita por quaisquer cidadãos, dado o fato do pluralismo ${ }^{14}$.

O grande problema, nesse ponto, seria justificar como uma concepção de justiça pode ser autossuficiente e independente de doutrinas morais abrangentes. Ora, se o julgamento do justo é um valor moral, característico de doutrinas abrangentes, a dificuldade está em dissociar a concepção política de justiça de suas bases abrangentes. Em suma, a questão passa a ser da possibilidade de distinguir a concepção política de justiça de uma doutrina moral abrangente sobre a justiça.

Ora, afirmar que o objeto da concepção política é diferente das pretensões gerais de uma doutrina abrangente não é suficiente para diferenciá-las. Isso porque não é necessário que as instituições orientem seu funcionamento por concepções políticas - podem adotar padrões e normas derivadas de doutrinas abrangentes, como em estados oficialmente religiosos. Assim, o problema está não somente em definir o locus de aplicação da concepção política, mas essencialmente em apontar como esta concepção consegue ser independente de doutrinas abrangentes em uma sociedade democrática.

Por isso, Rawls caracteriza a concepção política de justiça por seus conteúdos provirem de uma espécie de "cultura política pública de uma sociedade democrática"15. Tal cultura política é conhecida por meio das instituições de um regime constitucional, das tradições de interpretação dessas instituições, bem por meio de textos e documentos de conhecimento geral.

Com esse argumento, Rawls pretende distinguir a concepção política de justiça de alguma doutrina abrangente específica. Dessa forma, a teoria da 14 Como consequência das liberdades básicas, surge uma série de doutrinas e concepções religiosas, filosóficas e morais irreconciliáveis. Não é possível impedir que os cidadãos, livres em pensamento, crença e manifestação, adotem a doutrina conveniente para seus fins ou que inspire maior credibilidade. Por isso, as democracias necessitam enfrentar o fato do pluralismo, em que cada membro da sociedade tem a liberdade garantida para suas crenças. Assim, é impossível formular uma doutrina abrangente que possa orientar o funcionamento das instituições políticas, econômicas e sociais. É dessa necessidade de normas para instituições, que não podem prejudicar qualquer grupo de doutrinas abrangentes, que surge a proposição de uma concepção política de justiça.

15 RAWLS, John. O Liberalismo Político. Tradução de Dinah de Abreu Azevedo. 2. ed. São Paulo: Ática, 2000. p. 56. 
justiça equitativa não cercearia a liberdade básica de cada sujeito, respeitando o fato do pluralismo ${ }^{16}$. Assim, a concepção política formulada é dotada de três características: tem por objeto a estrutura básica da sociedade; é independente em relação a qualquer doutrina abrangente e seus preceitos são oriundos de ideias intuitivas presentes em uma cultura política pública ${ }^{17}$.

Por tal esquema teórico a concepção política de justiça adviria de uma cultura pública. Essa cultura pública seria o resultado do reconhecimento de regras oriundas de uma série de doutrinas abrangentes, adotadas livremente pelos membros da sociedade. Ocorre que tais doutrinas não são somente diferentes, mas muitas vezes opostas e conflitantes. Assim, são necessárias regras públicas conjuntamente reconhecidas, a fim de garantir a convivência pacífica e duradoura dos membros da sociedade ${ }^{18}$.

A referida cultura política pública é formada por regras reconhecidas pelos cidadãos, independentemente de suas escolhas pessoais - desde que estas sejam minimamente razoáveis (entenda-se aqui razoável como tolerante) ${ }^{19}$. Por

16 "Uma concepção da justiça deve ser suficientemente aberta para incluir modos de vida capazes de inspirar o devotamaento." RAWLS, John. Justiça e democracia. Tradução de Irene A Paternot. São Paulo: Martins Fontes, 2000. p. 294.

17 "As características de uma concepção política são, em primeiro lugar, que ela é uma concepção moral concebida para um campo específico, a estrutura básica de um regime democrático constitucional; em segundo lugar, que o fato de se aceitar essa concepção política não pressupõe a aceitação de uma doutrina abrangente particular qualquer. Ao contrário, a concepção política pretende valer unicamente para a estrutura básica da sociedade. E, em terceiro lugar, que ela é formulada não nos termos de uma doutrina abrangente qualquer, mas nos de certas ideias intuitivas fundamentais, consideradas como latentes na cultura política pública de uma sociedade democrática." (RAWLS, John. Justiça e democracia. Tradução de Irene A Paternot. São Paulo: Martins Fontes, 2000, p. 295).

18 "A cultura política de uma sociedade democrática é sempre marcada pela diversidade de doutrinas religiosas, filosóficas e morais conflitantes e irreconciliáveis. Algumas são perfeitamente razoáveis, e essa diversidade de doutrinas razoáveis, o liberalismo político a vê como o resultado inevitável, a longo prazo, do exercício das faculdades da razão humana em instituições básicas livres e duradouras. Por conseguinte, a segunda questão consiste em saber quais são os fundamentos da tolerância assim compreendida, considerando-se o fato do pluralismo razoável como resultado inevitável de instituições livres. A combinação dessas duas questões nos leva a perguntar como é possível existir, ao longo do tempo, uma sociedade justa e estável de cidadãos livres e iguais, mas que permanecem profundamente divididos por doutrinas religiosas, filosóficas e morais razoáveis." (RAWLS, John. O Liberalismo Político. Tradução de Dinah de Abreu Azevedo. 2. ed. São Paulo: Ática, 2000b, p.45-46).

19 Rawls escreveu em O Liberalismo Político, uma definição que tentou ser um pouco mais esclarecedora da noção de razoável. Aplicou essa noção indistintamente a pessoas e a doutrinas. Ao definir o que significa a razoabilidade de uma doutrina abrangente, escreveu, em nota de rodapé, que "Uma doutrina razoável é aquela que pode ser professada de for- 
isso, regras públicas de justiça são formuladas a partir de um consenso entre as doutrinas abrangentes, por mais conflitantes que sejam - conhecido como consenso sobreposto ${ }^{20}$.

Aqui, o aspecto da autossuficiência da concepção política de justiça merece ser esclarecido. A questão é como defender a autossuficiência de uma concepção se ela advém de outras - portanto, podendo resguardar conteúdos presentes em doutrinas abrangentes. Ao que se responde que a autossuficiência é representada pela neutralidade da formulação da concepção política.

A neutralidade não representa que a concepção política de justiça necessariamente é distinta de toda e qualquer doutrina abrangente. Ora, o que se pretende é a participação igual de cada membro ao formular a concepção política de justiça, qualquer que seja sua doutrina abrangente ou seu projeto de vida razoável. Essa neutralidade advém do processo de formulação da justiça política, muito embora seus conteúdos possam ser encontrados em noções abrangentes quaisquer. $O$ fato de os conteúdos da justiça política serem encontrados em doutrinas abrangentes é completamente indiferente para a neutralidade, que é garantida procedimentalmente ${ }^{21}$.

ma razoável" (RAWLS, 2000b, p. 104). Explicou que doutrinas abrangentes são exercícios concomitantes de razão teórica (organiza valores) e prática (restabelece equilíbrio quando valores entram em conflito), além de serem evolutivas ao longo do tempo. Essas doutrinas, embora estabeleçam verdades (ou pretendam), necessitam aceitar os limites do juízo ou seja, que nem todas as pessoas razoáveis professarão a mesma doutrina abrangente. (Idem, ibidem, p. 104).

20 O consenso sobreposto (ou consenso por justaposição) é elementar para garantir a estabilidade da concepção política de justiça válida para as instituições em uma sociedade democrática, considerando o fato do pluralismo razoável. (RAWLS, 2000a, p. 336). "Esse consenso abrange a todas as doutrinas religiosas, filosóficas e morais razoáveis e conflitantes que provavelmente se manterão ao longo de várias gerações e conquistarão um número considerável de adeptos num regime constitucional mais ou menos justo, um regime cujo critério de justiça é essa mesma concepção política." (RAWLS, John. O Liberalismo Político. Tradução de Dinah de Abreu Azevedo. 2.ed. São Paulo: Ática, 2000. p. 57).

21 A crítica à falta de neutralidade da concepção política de justiça desenvolvida por Rawls é enfrentada na obra $A$ justiça igualitária e seus críticos, de Álvaro de Vita (2007). Nessa obra, Vita expõe a diferença entre neutralidade de conteúdos e neutralidade procedimental. E sustenta a hipótese de que a neutralidade (ou autossustentabilidade) da justiça equitativa não é relacionada aos seus conteúdos, mas essencialmente ao procedimento de formulação da concepção política de justiça. A correlação possível entre a concepção política de justiça e doutrinas abrangentes, John Rawls expõe brevemente em O Liberalismo Político: "Suponho, então, que as visões globais dos cidadãos têm duas partes: pode-se considerar uma parte como a concepção política de justiça publicamente reconhecida, ou como coincidente com ela; a outra parte é uma doutrina (inteira ou parcialmente) abrangente, à qual a concepção política está ligada de alguma forma." (RAWLS, 2000b, p. 188). Rawls 
Então, essa concepção política é resultado de um consenso entre várias doutrinas abrangentes razoáveis e, portanto, de um conjunto de ideias de bem ${ }^{22}$. Convém aqui esclarecer que nenhuma das ideias de bem prevalece sobre outras, mas que todas são submetidas à concepção política de justiça. Somente assim é possível orientar o funcionamento das instituições básicas da sociedade sem comprometê-las especificamente com a promoção de algum ideal abrangente (e refutável ${ }^{23}$. Assim, surge o argumento da prioridade do justo sobre o bem ${ }^{24}$.

A prioridade do justo sobre o bem depende de uma definição do que seria o bem. Inicialmente, a primeira ideia de bem é identificada com racionalidade. Isso porque a ideia de bem representa a escolha de um projeto racional de

não enfrentou diretamente o problema de uma doutrina abrangente igualar-se à concepção política de justiça. Isso porque os objetos de uma concepção política de justiça e das doutrinas abrangentes são distintos. Mas certamente, se acaso as doutrinas abrangentes tenham conteúdos conformes à concepção política de justiça, de modo algum seria algo relevante e comprometedor da justiça política.

22 "As concepções religiosas e filosóficas tendem a ser globais e plenamente abrangentes; na verdade, são consideradas às vezes como um ideal a ser realizado." (RAWLS, John. $\mathbf{O}$ Liberalismo Político. Tradução de Dinah de Abreu Azevedo. 2. ed. São Paulo: Ática, 2000b, p. 222). Assim, as doutrinas abrangentes são verdadeiros sistemas que "incorporam o elemento regulador do nosso bem" (RAWLS, 2000c, p.610). E o racional é justamente a escolha de princípios e regras que viabilizem a realização dessa concepção do bem. (RAWLS, John. Uma teoria da justiça. Tradução de Altamiro Piseta e Lenita M. R. Esteves. São Paulo: 'Martins Fontes, 2000. p.450).

23 "A dificuldade está em que o Estado não pode agir com vistas a maximizar a satisfação das preferências racionais dos cidadãos ou das suas necessidades (como no utilitarismo), ou ainda com o fim de promover a excelência humana ou os valores de perfeição (como no perfeccionismo), tanto quanto não pode agir no intuito de promover o catolicismo, o protestantismo ou outra religião qualquer. Nenhuma dessas opiniões sobre o sentido, o valor e a finalidade da existência humana, definidas pelas concepções do bem correspondentes, de ordem religiosa ou filosófica, é adotada pelo conjunto dos cidadãos. Por conseguinte, a concretização de uma dentre elas por meio das instituições básicas daria ao Estado um caráter sectário. Para encontrar uma concepção comum do bem dos cidadãos que seja politicamente apropriada, o liberalismo político busca um ideia da vantagem racional definida por uma concepção política independente de qualquer doutrina abrangente particular e que possa tornar-se o centro de um consenso por justaposição." (RAWLS, John. Justiça e democracia. Tradução de Irene A Paternot. São Paulo: Martins Fontes, 2000, p.300-301)

24 "À guisa de prefácio, farei a seguinte observação geral: no quadro da teoria da justiça como equidade, a prioridade do justo implica que os princípios de justiça (política) impõem limites aos modos de vida que são aceitáveis; é por isso que as reivindicações que os cidadãos apresentam como fins que transgridem esses limites não têm peso algum (do ponto de vista da concepção política em questão). (....) Em suma, a justiça estabelece os limites, o bem indica a finalidade. (...) Essa prioridade quer dizer simplesmente que, se uma concepção política de justiça, para ser aceitável, deve respeitar formas de vida variadas às quais os cidadãos possam dedicar-se, não é menos verdade que as ideias do bem sobre as quais ela se apoia devem respeitar os limites - o espaço autorizado - fixados por ela própria." (RAWLS, John. Justiça e democracia. Tradução de Irene A Paternot. São Paulo: Martins Fontes, 2000, p. 294). 
vida, o qual direciona as decisões e os projetos pessoais dos membros de uma sociedade democrática.

Essa ideia primeira de bem conduz à análise dos bens primários - o minimamente necessário para a realização dos projetos de vida. São eles as liberdades, as oportunidades e os direitos básicos, mesmo acesso à renda e à riqueza e a mesma base social de respeito próprio ${ }^{25}$. Os bens primários correspondem às reivindicações válidas dos membros de uma sociedade democrática.

Assim, o limite das doutrinas abrangentes, ou das concepções de bem, está na própria concepção de bens primários. Esses bens são igualmente distribuídos a todos os membros, pois são necessários à realização de quaisquer dos projetos de vida razoáveis. A distribuição equitativa desses bens deve ocorrer porque as instituições não são comprometidas com qualquer projeto específico.

Então, a noção de bem é um elemento fundamental para a conformação das doutrinas abrangentes razoáveis a uma concepção política de justiça. Por isso, bem e justo são complementares e igualmente relevantes ${ }^{26}$. Entretanto, é de se ressaltar que a prioridade do justo é o que apresenta os limites políticos ao que, institucionalmente, pode ser exigido pelos membros da sociedade.

25 Estes correspondem à lista não exaustiva de bens primários elencados por Rawls. Consultar O Liberalismo Político, p. 227-228. "A lista de bens primários (que pode aumentar, caso seja necessário) pode ser dividida nas cinco categorias seguintes: a. os direitos e liberdades fundamentais, que também constituem uma lista; b. liberdade de movimento e livre escolha de ocupação num contexto de oportunidades diversificadas; c. poderes e prerrogativas de cargos e posições de responsabilidade nas instituições políticas e econômicas da estrutura básica; d. renda e riqueza e bases sociais do auto-respeito."

26 "Assim, o justo e o bem são complementares, o que a prioridade do justo não nega em absoluto." (RAWLS, John. Justiça e democracia. Tradução de Irene A Paternot. São Paulo: Martins Fontes, 2000, p. 294). O que se pretende é que as concepções de bem e os projetos de vida detenham um limite público mínimo. Esse limite é dado pela possibilidade de convivência e respeito a outros projetos de vida. A aceitação de pontos de vista e julgamentos morais diferentes é característica de uma cultura política democrática e constitui um limite público à escolha racional. É lícita a escolha de qualquer projeto de bem pelo membro da sociedade. É racional, quando a concepção de bem conduz a projetos de vida adequados a suas condições de realização. Além disso, é necessário, para que seja aceito pela justiça política, que aceite os limites do juízo. Esses limites se referem à capacidade que cada membro tem de julgar e escolher determinada concepção do bem. O que significa dizer que os projetos de vida, derivados de concepções do bem, necessariamente devem aceitar o fato de conviver com outros projetos de vida, ou mesmo outras verdades. O que significa que um sistema de verdades deve conseguir aceitar seu oposto, posto que há limites em que os cidadãos irão discordar. Dessa forma, as concepções de bem são limitadas por um senso de justiça política, que possibilita a existência de uma diversa gama de projetos de vida na sociedade. 
Assim, a ideia de bem como racionalidade serve à identificação dos bens primários, bem como à identificação dos objetivos racionais das partes no momento da formulação da concepção política de justiça. A motivação da justiça política necessita dessa racionalidade, a fim de constituir uma concepção de justiça amplamente aceitável por quaisquer doutrinas abrangentes e tolerantes com outras que possam surgir numa sociedade democrática.

É preciso definir, nesse momento, como opera essa racionalidade na formulação da concepção política de justiça. Isso porque essa concepção de justiça é formulada (ou aceitável) por membros de uma sociedade democrática. Esses membros são dotados de certas capacidades que se desenvolvem sob uma cultura pública política - como a racionalidade. Segue uma síntese da concepção de pessoa e de suas capacidades morais, a fim de que se possa verificar como Rawls definiu a capacidade do racional, bem como a importância da racionalidade na formação de uma concepção política de justiça.

\section{AS PARTES E A RACIONALIDADE NA POSIÇÃO ORIGINAL}

Para formular uma concepção política de justiça publicamente aceita pelos membros de uma sociedade democrática, é necessário seguir um procedimento de construção. Esse procedimento é caracterizado pela participação de agentes racionais que, sob condições de profunda igualdade, formulam os princípios que orientarão o funcionamento das instituições básicas da sociedade.

Os agentes racionais, usando de sua razão prática e a partir de diversas perspectivas de bem, conseguem atingir um consenso sobre os princípios a serem seguidos. Tais princípios são somente voltados para o funcionamento institucional e, por isso, Ihes é indiferente qualquer inferência sobre suas convicções a respeito da verdade.

Essa característica define o construtivismo político de John Rawls do construtivismo moral kantiano ${ }^{27}$. Isso porque o resultado esperado da concepção política de justiça 27 "Para explicar o construtivismo político, precisamos fazer três perguntas. Primeira: nesse tipo de construtivismo, qual é o objeto construído? Resposta: o conteúdo de uma concepção política de justiça. (...) A segunda pergunta é: enquanto artifício procedimental de representação, a própria posição original é construída? Não, ela é somente estipulada. 
são princípios cujos conteúdos orientam o funcionamento institucional. E tais princípios são formulados por cidadãos racionais e razoáveis, considerados livres e iguais - em um momento hipotético denominado "posição original"28.

Os cidadãos, em uma sociedade democrática, professam qualquer doutrina moral abrangente razoável (que consegue aceitar os limites públicos da razão ou do juízo). Mas, no momento intitulado como posição original, os membros da sociedade não detêm conhecimento de suas concepções pessoais. Mesmo assim sabem dispor racionalmente de sua posição e, na tentativa de resguardar para si maior número de bens primários o possível ${ }^{29}$, usam de sua faculdade racional para estipular os princípios que fundamentam uma concepção política de justiça.

No momento da formulação dos princípios de justiça característicos da concepção política, os membros da sociedade são capazes de antever que deterão uma concepção de bem, embora ainda não acessem seus conteúdos. Ou seja, terão projetos de vida, mas ainda não sabem qual. Por isso, são dotados de uma capacidade de julgar um plano de distribuição de bens primários que não os prejudiquem no futuro. E mais, são motivados tendo em consideração sua

(...) Isso leva à terceira pergunta: o que significa dizer que as concepções de cidadão e de uma sociedade bem-ordenada estão incrustadas no procedimento construtivista ou são modeladas por ele? Significa que a forma do procedimento e suas características mais peculiares são obtidas dessas concepções que lhes servem como base." (RAWLS, John. O Liberalismo Político. Tradução de Dinah de Abreu Azevedo. 2.ed. São Paulo: Ática, 2000. p. 148-149)

28 "A posição original não deve ser considerada como uma assembleia geral que inclui, num dado momento, todas as pessoas que vivem numa determinada época; e menos ainda como uma assembleia de todos os quer poderiam viver numa determinada época. Ela não é uma reunião de todas as pessoas reais ou possíveis. Se concebermos a posição original de uma dessas duas maneiras, a concepção deixaria de ser um guia natural para a intuição e não teria um sentido claro. De qualquer forma, a posição original deve ser interpretada de modo que possamos, a qualquer tempo, adotar a sua perspectiva. Deve ser indiferente a ocasião em que alguém adota esse ponto de vista, ou quem o faz: as restrições devem ser tais que os mesmos princípios são sempre escolhidos." (RAWLS, John. Uma teoria da justiça. Tradução de Altamiro Piseta e Lenita M. R. Esteves. São Paulo: 'Martins Fontes, 2000, p.149).

29 "O conceito de racionalidade invocado aqui, a não ser por uma característica essencial, é aquele conceito clássico famoso na teoria social. Assim, de forma genérica, considera-se que uma pessoa racional tem um conjunto de preferências entre as opções que estão a seu dispor. Ela classifica essas opções de acordo com sua efetividade em promover seus propósitos; segue o plano que satisfará uma quantidade maior de seus desejos, e que tem as maiores probabilidades de ser implementado com sucesso." (RAWLS, John. Uma teoria da justiça. Tradução de Altamiro Piseta e Lenita M. R. Esteves. São Paulo: 'Martins Fontes, 2000, p. 154) 
possível posição particular na distribuição dos bens ${ }^{30}$. Essa é a capacidade moral da racionalidade das partes na posição original hipotética ${ }^{31}$.

A racionalidade significa a capacidade de escolher os princípios de justiça equilibrados, voltados para a realização de um projeto de vida, e de ser capaz de orientar-se pela realização desse projeto ${ }^{32}$. Como na posição original nenhuma das partes tem conhecimento de seu status futuro, e são ao mesmo tempo racionais, aceitariam princípios de justiça equilibrados, sem maiores prejuízos a outras partes.

Por isso, o fundamento da posição original é a existência de cidadãos livres e iguais, capazes de acordo em termos equitativos. Para viabilizar essa capacidade racional, são excluídas suas posições pessoais do campo de escolha e justificação. Isso porque "o dado de ocuparmos certa posição social não é uma razão válida para que aceitemos, ou esperemos que outros aceitem, uma concepção de justiça que favoreça os que ocupam essa posição." 33

Dessa forma, as contingências sociais e históricas são completamente indiferentes no momento de formulação de uma concepção política de justiça. Essa é a única via para construir uma concepção de justiça duradoura para 30 "Supus até aqui que as pessoas na posição original são racionais. Mas também presumi que elas não conhecem a sua concepção do bem. Isso que dizer que, embora saibam que têm algum plano racional de vida, elas não conhecem os detalhes desse plano, os objetivos e os interesses particulares que ele busca promover. Como podem então decidir quais concepções da justiça Ihes trazem mais benefícios? Será que devemos supor que essas pessoas estão reduzidas à mera emissão de palpites? Para enfrentar essa dificuldade, postulo que elas aceitam a explicação do bem que foi abordada no capítulo anterior: essas pessoas supõem que geralmente preferem ter uma quantidade de bens sociais primários maior ao invés de uma menor." (Idem, ibidem, p. 153).

31 Consideremos que a posição original não corresponde a uma situação histórica - antes é um recurso hipotético, a fim de determinar as condições para a formulação de uma concepção política de justiça. Nesse momento hipotético, "as partes são pessoas artificiais, situadas dentro de um dispositivo de representação, são apenas racionais". (RAWLS, John. O Liberalismo Político. Tradução de Dinah de Abreu Azevedo. 2.ed. São Paulo: Ática, 2000, p. 149).

32 A racionalidade aqui representa "(...)a faculdade moral de ter uma concepção de bem" (RAWLS, John. $\mathbf{O}$ Liberalismo Político. Tradução de Dinah de Abreu Azevedo. 2.ed. São Paulo: Ática, 2000, p.73). O que falta à racionalidade é o desejo que entrar em um sistema de cooperação equitativa, o que só pode ser garantido pela razoabilidade. Pela capacidade racional, o agente é capaz de escolher entre os projetos de bem, mas não necessariamente essa escolha recairá sobre projetos equitativos. Segundo Rawls, "os agentes racionais tornam-se quase psicopatas quando seus interesses se resumem a benefícios para si próprios." (Idem, ibidem, p.95)

33 RAWLS, John. Justiça e democracia. Tradução de Irene A Paternot. São Paulo: Martins Fontes, 2000. p. 221. 
uma sociedade democrática. Veja-se - ao serem considerados os pontos de vista particulares e contingentes, há o recurso às doutrinas abrangentes. $O$ problema é que doutrinas abrangentes não conseguem formular princípios de justiça públicos estáveis ao longo do tempo. Ao menos não quando se trata de sociedades democráticas, nas quais não há (e nem seria lícito existir) controle sobre as doutrinas abrangentes que possam ser afirmadas por seus membros, dado o rol de liberdades básicas individuais.

O afastamento das partes que compõem a posição original em relação ao conhecimento contingente é o que evita o comprometimento da concepção política de justiça com alguma doutrina abrangente específica. A esse expediente Rawls denominou como "véu de ignorância" - é o que resguarda a possibilidade de um acordo equitativo sobre a justiça política, além de preservar a igualdade entre as partes ${ }^{34}$.

Assim, na posição original, as partes que irão formular a concepção política de justiça são livres e iguais, e estão colocadas em igualdade de posição. Nesses termos, é possível pensar em uma concepção de justiça que estabeleça termos equitativos de cooperação social, efetivando nas instituições as liberdades básicas e a igualdade de oportunidades ${ }^{35}$.

Apesar do véu de ignorância e, portanto, do desconhecimento de posições sociais, políticas e econômicas atuais e futuras, as partes, na posição original, escolhem princípios de justiça fundamentais à concepção política de justiça ${ }^{36}$.

34 "Devemos encontrar um ponto de vista - distanciado e não deformado pelos traços e pelo contexto particulares do quadro global - a partir do qual se possa atingir um acordo equitativo entre pessoas livres e iguais. É esse ponto de vista, com a característica particular que chamei de "véu de ignorância", que constitui a posição original. E a razão pela qual a posição original não deve ter em conta as contingências do mundo social nem ser afetada por elas é que as condições de um acordo equitativo sobre os princípios de justiça política entre pessoas livres e iguais devem eliminar as desigualdades na distribuição dos trunfos na negociação, os quais não deixarão de suscitar, nas instituições de qualquer sociedade, as tendências acumuladas naturais, sociais e históricas. Essas vantagens vindas do passado não devem influenciar um acordo sobre os princípios que devem reger as instituições da própria estrutura básica desde o momento presente até o futuro." (RAWLS, 2000a, p. 219).

35 "Introduzimos uma ideia como a da posição original porque não parece haver forma meIhor de elaborar uma concepção política de justiça para a estrutura básica a partir da ideia fundamental da sociedade como um sistema duradouro e equitativo de cooperação entre cidadãos considerados livres e iguais." (RAWLS, John. O Liberalismo Político. Tradução de Dinah de Abreu Azevedo. 2.ed. São Paulo: Ática, 2000. p. 69).

36 "A ideia da posição original é estabelecer um processo equitativo, de modo que quaisquer 
Mesmo sob o véu de ignorância, as partes são capazes de escolher princípios adequados aos seus propósitos de vida em geral. Isso porque a motivação moral necessária à formulação dos princípios de justiça política não é eliminada pelo véu de ignorância ${ }^{37}$. O desejo de estabelecer termos equitativos de cooperação social não é encoberto pelo véu de ignorância e tampouco depende do conhecimento de circunstâncias contingentes.

A escolha dos princípios para a formulação de uma concepção política de justiça, efetuada posição original, sob o véu de ignorância, recai princípios equilibrados e justos. Isso ocorre porque a posição original detém três características: a primeira delas, as partes são dotadas de racionalidade. A segunda, a condição de liberdade e igualdade das partes. A terceira, porque essas condições iniciais são mantidas ao longo do tempo.

A racionalidade das partes é compreendida como a capacidade moral de escolher princípios de justiça, publicamente acordados e válidos, que possam trazer maiores benefícios a quaisquer que sejam as doutrinas abrangentes que

princípios aceitos sejam justos. O objetivo é usar a noção de justiça procedimental pura como fundamento da teoria. De algum modo, devemos anular os efeitos das contingências específicas que colocam os homens em posições de disputa, tentando-os a explorar as circunstâncias naturais e sociais em seu próprio benefício." (...) "Elas devem escolher princípios cujas consequências estão preparadas para aceitar, não importando a qual geração pertençam" (RAWLS, John. Uma teoria da justiça. Tradução de Altamiro Piseta e Lenita M. R. Esteves. São Paulo: 'Martins Fontes, 2000, p. 147). Além disso, afirma o autor "introduzimos uma ideia como a da posição original porque não parece haver melhor forma de elaborar uma concepção política de justiça para a estrutura básica a partir da ideia fundamental da sociedade como um sistema duradouro e equitativo de cooperação entre cidadãos considerados livres e iguais." (RAWLS, John. O Liberalismo Político. Tradução de Dinah de Abreu Azevedo. 2. ed. São Paulo: Ática, 2000, p. 69)

37 Para alguns críticos, a condição do véu de ignorância acarreta a irracionalidade na escolha dos princípios de justiça. Isso porque a decisão racional necessita de um máximo de informações possíveis para ser tomada. Segundo Rawls, "Com certeza, alguns podem objetar que os princípios de justiça deveriam ser escolhidos à luz de todo o conhecimento disponível" (RAWLS, John. Uma teoria da justiça. Tradução de Altamiro Piseta e Lenita M. R. Esteves. São Paulo: Martins Fontes, 2000. p. 149). O argumento de Rawls é contrário, defendendo o véu de ignorância, pois este seria necessário para a adoção de princípios efetivamente racionais, unânimes e duradouros. Isso porque todo e qualquer membro da sociedade, sob o véu de ignorância, evitaria princípios desequilibrados quanto à distribuição dos bens primários e das liberdades básicas. Esse efeito equitativo se manifestaria em princípios válidos não somente para as instituições no presente, mas também para as próximas gerações. Ver detalhes em Uma teoria da justiça, 2000, p. 149 e ss. Em verdade, a motivação para a formulação de uma concepção política de justiça não está adstrita à realização de um projeto particular de bem - antes é dada pelo desejo de estabelecer termos de cooperação equitativa. E para estabelecer tais termos, é completamente irrelevante o conhecimento de contingências particulares. 
venham a professar. As partes, portanto, "tomariam uma decisão racional em sentido comum"38.

A racionalidade exige que não sejam cogitadas ideias de justiça que prevejam prejuízos a quaisquer dos membros da sociedade. Isso porque os próprios agentes racionais não estabeleceriam posições deliberadamente prejudicadas, pois poderiam ser sujeitos dessa posição assim que dissipado o véu de ignorância. Por isso, a racionalidade das partes, na posição original, é mutuamente desinteressada. Assim, não são previstos vantagens ou prejuízos - antes, são escolhidos princípios equitativos ${ }^{39}$.

O fato de a posição original ser caracterizada pelo véu de ignorância garante a liberdade e a igualdade das partes nesse momento hipotético inicial. 0 desconhecimento das condições particulares e circunstanciais de cada membro faz com que todos sejam igualmente considerados. Isso reduz o poder de barganha entre as partes. E essa é a condição para evitar a formulação de princípios que possam estabelecer benefícios especiais em detrimento de outros membros da sociedade ${ }^{40}$.

Por último, a consequência da manutenção no tempo das condições de igualdade e liberdade das partes. Ora, como não se conhece a posição ocupada no presente, também não se pode garantir às futuras gerações outras condições que não sejam a profunda igualdade com o maior número de liberdades garantidas. Ademais, a concepção política de justiça constitui uma cultura política pública, que, legada às futuras gerações, tende a se perpetuar. Isso porque o artifício da posição original pode ser acessado a qualquer tempo no futuro, dado que exige unicamente a racionalidade das partes ${ }^{41}$.

38 RAWLS, John. Uma teoria da justiça. Tradução de Altamiro Piseta e Lenita M. R. Esteves. São Paulo: 'Martins Fontes, 2000, p. 154

39 "A suposição da racionalidade mutuamente desinteressada, portanto, resulta nisto: as pessoas, na posição original tentam reconhecer princípios que promovem seus sistemas de objetivos da melhor forma possível. Elas fazem isso tentando garantir para si mesmas o maior índice de bens sociais rimários, já que isso lhes possibilita promover a sua concepção do bem de forma efetiva, independentemente do que venha a ser essa concepção. As partes não buscam conceder benefícios ou impor prejuízos umas às outras; não são movidas nem pela afeição e nem pelo rancor. Nem tentam levar vantagens umas sobre as outras; não são invejosas ou vaidosas." (RAWLS, 2000c, p. 155)

40 "Assim, decorre a importantíssima consequência de que as partes não têm base para negociar no sentido usual. Ninguém conhece a sua situação na sociedade nem os seus dotes naturais, e portanto ninguém tem possibilidade de formular princípios sob medida para favorecer a si próprio." (Idem, ibidem, p.150)

41 "De qualquer forma, a posição original deve ser interpretada de modo que possamos, a qualquer tempo, adotar sua perspectiva. Deve ser indiferente a ocasião em que alguém 
A questão é que a racionalidade das partes, sua liberdade e igualdade comprometem a concepção política de justiça necessariamente com uma concepção de pessoa - aquela capaz de formular e aceitar os princípios equitativos de justiça na posição original. Essa noção de pessoa corresponde exatamente aos indivíduos morais que aceitam os princípios de justiça. Para evitar a vinculação da justiça política com um ideal metafísico de pessoa ${ }^{42}$ e, portanto, com alguma doutrina abrangente, Rawls descreve uma concepção política de pessoa. Essa concepção apenas estipula uma pessoa moral no campo político, sem abrangência sobre a psicologia e as decisões privadas. Seria uma concepção de pessoa que determina as capacidades morais políticas necessárias para a construção de uma concepção unicamente política de justiça.

Essa concepção política de pessoa define as partes como seres considerados livres e iguais. São assim não por pressupostos metafísicos, mas porque possuem duas faculdades morais necessárias para a concepção política de justiça - a racionalidade (expressa como capacidade de ter uma concepção do bem) e a razoabilidade (ou senso de justiça). Essas são as duas faculdades suficientes e necessárias, segundo Rawls, para a aceitação de termos equitativos de cooperação social e para a formulação dos princípios da concepção política de justiça. ${ }^{43}$

Além disso, a liberdade da pessoa política é estabelecida pelo reconhecimento mútuo de que são todos capazes de terem uma concepção do bem ${ }^{44}$. Outro nível

adota esse ponto de vista, ou quem o faz: as restrições devem ser tais que os mesmo princípios são sempre escolhidos." (RAWLS, 2000c, p.149).

42 "Acabo de mostrar que a ideia da posição original e a descrição dos parceiros poderiam fazer-nos pensar que está pressuposta uma doutrina metafísica da pessoa. Quando digo que tal interpretação seria um erro, não basta simplesmente descartar o recurso às doutrinas metafísicas porque, malgrado as nossas intenções, elas podem sempre estar presentes." (RAWLS, 2000a, p. 225) (RAWLS, 2000b, p. 72). O argumento de Rawls para evitar tal crítica é que não há formulação clara sobre o que seria uma concepção metafísica de pessoa, o que, portanto, exime sua teoria dessa crítica - pois ela não teria sentido.

43 RAWLS, John. O Liberalismo Político. Tradução de Dinah de Abreu Azevedo. 2. ed. São Paulo: Ática, 2000. p. 78.

44 "Primeiro, os cidadãos são livres no sentido de conceberem a si mesmo e aos outros como indivíduos que tem a faculdade moral de ter uma concepção do bem." (RAWLS, 2000b, p. 73). Entretanto, os indivíduos são livres para a escolha e para mudar suas escolhas a respeito da concepção do bem. Não há qualquer compromisso do indivíduo com determinada concepção do bem, podendo reavaliar sua escolha e mudar a qualquer tempo. Esse fato em nada afeta o compromisso com uma concepção política de justiça, visto que são esferas de comprometimento distintas. A pessoa pode escolher qualquer concepção razoável do bem - isso não implica que mudará de postura política. Rawls, nessa altura, constrói um argumento levando 
da liberdade política da pessoa é que todos reconhecem o direito de apresentar reivindicações às instituições, de maneira a promover suas concepções do bem ${ }^{45}$ 46. E, em terceiro lugar, as pessoas são livres porque são capazes de assumir responsabilidades por seus objetivos. Isso significa dizer que a) são capazes de ajustar seus objetivos ao que é possível fazer e b) que aceitam os limites estabelecidos pelos princípios de justiça. Esses três aspectos comprovam, para Rawls, que a concepção de pessoa livre e igual não é metafísica, mas política. Além dessas características, some-se o fato de que o reconhecimento da liberdade e da igualdade da pessoa é dado por uma cultura política pública ${ }^{47}$.

A pessoa política pressuposta por Rawls, livre e igual, é necessariamente dotada de racionalidade para a escolha de seus projetos de bem, tanto quanto deseja estabelecer termos equitativos de cooperação social. Mais ainda, o próprio autor comenta que essas duas capacidades morais são complementares e necessárias ${ }^{48}$. Portanto, a pessoa política é aquela que, além de determinar projetos de vida, o faz tendo como limite os termos da equitativa cooperação social. Veja-se, a seguir, como tal concepção pode ser problematizada e deter pressupostos de ordem metafísica - o que representaria sério problema quanto à autossustentabilidade da concepção política de justiça rawlsiana.

em consideração a postura do apóstolo Paulo, que mudou seu comportamento e seu nome, mas não implicou em qualquer mudança em sua identidade pública ou institucional.

45 Segundo Rawls, somente há possibilidade de reivindicar institucionalmente caso haja reconhecimento da liberdade política do sujeito. A possibilidade de reivindicação é boa prova da liberdade do sujeito. Isso porque considera Rawls que os escravos não eram (ou são) capazes dessas reivindicações institucionais - não são aceitos pelas instituições como pessoas.

46 RAWLS, John. O Liberalismo Político. Tradução de Dinah de Abreu Azevedo. 2. ed. São Paulo: Ática, 2000. p. 76.

47 "Segundo, nesta seção, examinamos três aspectos segundo os quais as pessoas são consideradas livres e notamos que, na cultura política pública de um regime democrático constitucional, os cidadãos concebem a si mesmos como livres nesses aspectos." RAWLS, John. $\mathbf{O}$ Liberalismo Político. Tradução de Dinah de Abreu Azevedo. 2.ed. São Paulo: Ática, 2000. p. 78. Para Krischke (1998, p.317), Rawls supõe uma condição de publicidade baseada em uma densa tradição cultural e institucional, o que pode soar extremamente idealizado, se consideradas empiricamente as instituições.

48 "Dentro da ideia de cooperação equitativa, o razoável e o racional são noções complementares. Ambos são elementos dessa ideia fundamental, e cada um deles conecta-se com uma faculdade moral distinta - respectivamente, com a capacidade de ter senso de justiça e com a capacidade de ter uma concepção do bem. Ambos trabalham em conjunto para especificar a ideia de termos equitativos de cooperação, levando-se em conta o tipo de cooperação social em questão, a natureza das partes e a posição de cada um em relação à outra." "Pode-se ver como essas duas ideias operam em conjunto na estruturação da posição original." RAWLS, John. O Liberalismo Político. Tradução de Dinah de Abreu Azevedo. 2. ed. São Paulo: Ática, 2000. p. 96. 


\section{AS CAPACIDADES MORAIS DO SUJEITO E A CONCEPÇÃO MORAL DE JOGO EM UMA TEORIA DA JUSTIÇA - EXCLUSÃO DO JOGADOR}

A concepção política de justiça tem suas bases em princípios publicamente acordados, cujo objeto é o funcionamento das instituições públicas que compõem a estrutura básica da sociedade. Ocorre que, para a formulação pública dos princípios de justiça, é imprescindível a existência de cidadãos com determinadas capacidades, que estejam dispostos ao estabelecimento desses princípios.

Por ser uma concepção de justiça publicamente construída, é essencial a ideia de liberdade e igualdade dos membros da sociedade. Para tanto, o recurso ao véu de ignorância na posição original garante essa igualdade entre as partes. Essa igualdade evita barganhas políticas e o estabelecimento de princípios de justiça políticos que desequilibrem as partes. E é importante aos princípios de justiça que estabeleçam o funcionamento institucional e o resguardo da liberdade e da igualdade entre os cidadãos, pois é essa característica que garante a estabilidade em uma sociedade democrática.

Então, a posição original é o instrumento necessário à formulação de princípios de justiça conforme uma concepção política ${ }^{49}$. Entretanto, apenas a existência de cidadãos sob o véu de ignorância não garante a escolha de princípios de justiça equitativos. Isso porque os membros da posição original poderiam escolher princípios que representassem desvantagem a alguma posição social. Ora, somente ignorar o status futuro não compromete o cidadão na escolha de princípios de justiça equitativos. Alguma das partes pode tentar arriscar a fortuna, estabelecendo privilégios e prejuízos a posições sociais diversas, na tentativa de posições avantajadas futuramente.

Os princípios equitativos de justiça são importantes para a formulação de uma concepção de justiça duradoura no tempo. A ideia de estabilidade é a justificativa da construção dos princípios de justiça conforme o design proposto ${ }^{50}$. 49 "Afirmei que a posição original é o status quo inicial apropriado para assegurar que os consensos básicos nele estabelecidos sejam equitativos. Esse fato delimita o conceito de 'justiça como equidade'" RAWLS, John. Uma teoria da justiça. Tradução de Altamiro Piseta e Lenita M. R. Esteves. São Paulo: Martins Fontes, 2000. p. 19.

50 "É melhor apresentar a justiça como equidade em dois estágios. No primeiro estágio, ela é articulada como uma concepção política (e moral, evidentemente) autossustentada para 
Seria como pressupor que a distribuição de bens e liberdades básicas segundo princípios equitativos possa garantir a estabilidade institucional às democracias contemporâneas. Aqui, há um pressuposto fundamentalmente racionalizante e ideal de Rawls a respeito da atividade política, o que poderia ser alvo de maiores críticas em outro trabalho ${ }^{51}$.

Enfim, essa concepção política de justiça, que necessita ser equitativa para ser estável, não é garantida somente pelo expediente argumentativo da posição original. É necessário que as partes sob o véu de ignorância tenham certas capacidades morais. E a capacidade marcante que as partes detêm na posição original é a racionalidade ${ }^{52}$.

A racionalidade das partes, na posição original, é a capacidade moral que permite, a cada cidadão, aceitar princípios políticos de justiça que garantam a realização de seus propósitos e que não prejudique o sistema de objetivos dos demais. Até porque, para Rawls, o objetivo do agente não é o prejuízo dos outros

a estrutura básica da sociedade. Somente depois disso, e com seu conteúdo - princípios de justiça e ideais - provisoriamente formulado, é que enfrentamos, no segundo estágio, o problema de saber se a justiça como equidade é suficientemente estável. Se não forma, não se trata de uma concepção política satisfatória de justiça, devendo ser revista de alguma forma" RAWLS, John. O Liberalismo Político. Tradução de Dinah de Abreu Azevedo. 2.ed. São Paulo: Ática, 2000 p. 186.

51 Ora, o pressuposto de que princípios equitativos necessariamente conduzam à estabilidade institucional é pressupor que a atividade política não é gerenciada por interesses. Rawls poderia responder a essa crítica devolvendo as partes à posição original. Entretanto, esse expediente necessitaria ser recorrido a todo e qualquer instante de deliberação pública, de maneira que as democracias seriam identificadas com a própria posição original. Dessa maneira, haveria uma forte exigência sobre a democracia (ou fé) - o que talvez Rawls procurou minimizar ao construir uma concepção política de pessoa. Pode-se, nesse ponto, especular o próprio esvaziamento da atividade política por esse ideal. Isso porque as partes, em uma democracia constitucional, necessitariam praticamente conviver na posição original, o que justamente elimina a possibilidade da vida democrática (considerando que seja esta a convivência com demais doutrinas abrangentes). O argumento de Rawls sobre o senso de justiça recorre às doutrinas abrangentes para fornecer uma aceitabilidade da concepção política de justiça. E, por essa via, o comprometimento motivacional da justiça equitativa com as doutrinas abrangentes pode ser levantado.

52 "Está claro, portanto, que eu quero afirmar que uma concepção de justiça é mais razoável que outra, ou mais justificável no que diz respeito à 'justiça como equidade', quando pessoas racionais na situação inicial escolhem seus princípios para o papel da justiça, preferindo-os aos de outra concepção. As concepções da justiça devem ser classificadas por sua aceitabilidade perante pessoas nessas circunstâncias. Entendida dessa forma, a questão da justificativa se resolve com a solução d um problema de deliberação: precisamos definir quais princípios seriam racionalmente adotados dada a situação contratual. Isso associa a questão da justiça à teoria da escolha racional" (RAWLS, John. Uma teoria da justiça. Tradução de Altamiro Piseta e Lenita M. R. Esteves. São Paulo: 'Martins Fontes, 2000. p. 19). 
(lembre-se de que as partes não são invejosas ou vaidosas), mas o incremento mútuo de seus bens e liberdades básicas ${ }^{53}$.

Por isso, na concepção de Rawls, a ideia de jogo não se aplicaria à justiça equitativa ${ }^{54}$. Isso porque no jogo, segundo o autor, "as partes estão interessadas em ganhar"55. Se as partes são motivadas pelo ganho, haveria a previsão da posição do perdedor. E tal previsão acarretaria prejuízo a uma das partes - ainda que não se saiba a quem estará destinada tal posição. Então, o jogo não é uma concepção racional para a justiça política.

O importante é que a noção de perdedor não é compatível com termos equitativos de cooperação. E mais, o jogo não seria uma perspectiva eficiente para motivar uma decisão racional. Ora, considere que a racionalidade é a capacidade moral da pessoa política que possibilita a escolha de princípios de justiça equitativos. Esses princípios são aceitos porque, racionalmente, em uma situação de plena igualdade e de desconhecimento das condições contingentes (presentes e futuras), não seria de se esperar que os agentes previssem a possibilidade de uma posição de perdedor. Isso porque nenhum membro da sociedade aceitaria para si tal posição ${ }^{56}$.

53 "A suposição especial que faço é que o indivíduo racional não é acometido pela inveja. Ele não está disposto a aceitar uma perda para si mesmo apenas para que os outros também obtenham menos. Não fica desanimado por saber ou perceber que os outros tem uma quantidade de bens sociais primários maior que a sua. Ou, pelo menos, isso se verifica na medida em que as diferenças entre esse indivíduo e os outros não exceda certo limite, e que ele não acredite que as desigualdades existentes estão fundadas na injustiça ou resultam da aceitação do acaso, sem nenhum propósito social visando compensá-las." (idem, ibidem, p. 154).

54 "As partes não buscam conceder benefícios ou impor prejuízos umas às outras; não são movidas nem pela afeição nem pelo rancor. Nem tentam levar vantagens umas sobre as outras; não são invejosas ou vaidosas. Falando em termos de um jogo, poderíamos dizer: elas lutam pelo maior número absoluto de pontos possíveis. Não desejam para seus oponentes um número de pontos alto ou baixo, nem buscam maximizar ou minimizar a diferença entre seus sucessos e os dos outros. A ideia de um jogo não se aplica de fato, pois as partes não estão interessadas em ganhar, mas em obter todos os pontos possíveis, a julgar pelo seu próprio sistema de objetivos." (RAWLS, 2000c, p. 156). (grifo nosso)

55 RAWLS, John. Uma teoria da justiça. Tradução de Altamiro Piseta e Lenita M. R. Esteves. São Paulo: Martins Fontes, 2000. p. 156.

56 "Consideremos então o ponto de vista de uma pessoa qualquer na posição original. Essa pessoa não tem meios de obter vantagens especiais para si mesma. Por outro lado, também não há fundamentos para que ela concorde com desvantagens especiais. Como não é razoável que ela espere mais do que uma parte igual na divisão dos bens sociais primários, e como também não é racional que ela concorde em obter menos, o sensato é reconhecer, como o primeiro passo, um princípio que exija uma distribuição igual." (RAWLS, John. Uma teoria da justiça. Tradução de Altamiro Piseta e Lenita M. R. Esteves. São Paulo: Martins Fontes, 2000, p.162) 
Assim, Rawls rechaça a noção de jogo da justiça equitativa. A motivação que acarreta a escolha de princípios equitativos para a estrutura básica da sociedade é racional - o querer resguardar para si, mediante as condições da posição original, a maior parcela de bens primários quanto possível. A postura de assumir riscos, resguardando posições privilegiadas, por esse argumento, seria completamente irracional ${ }^{57}$.

Quanto ao jogador, este estaria distante da descrição das partes na posição original rawlsiana. Sua postura de apostar tudo, de arriscar sofrer prejuízos, não é condizente com os sujeitos da posição original ${ }^{58}$. Estes estão comprometidos com a distribuição equitativa dos bens sociais, uma vez que não conhecem qual status terão no futuro.

Já o jogador não se compromete com o ganho equitativo: deseja o maior lucro para si, ainda que diante do risco de sua própria ruína. Não lhe é importante se a ruína possa ser a sua própria; o que determina sua ação é o desejo de obter a maior vantagem, mesmo que para isso tenha que aceitar o possível prejuízo próprio. O risco vale a pena para o jogador; já para o sujeito rawlsiano, o risco não é desejável. Por isso aceita a situação de equidade proporcionada pelos princípios de justiça.

Além disso, o sujeito rawlsiano não admite a sorte, ou a aposta, como critério de escolha racional. A concepção política de pessoa racional, necessária à formulação da justiça política, exclui o jogador como sujeito moral. Assim, a justiça equitativa pode ser compreendida como uma concepção de bem que, a partir de preceitos

57 Entretanto, a distribuição igual dos bens não é necessariamente uma posição definitiva. Segundo Rawls, "A sociedade deve levar em consideração a eficiência econômica e as exigências organizacionais e tecnológicas. Se existem desigualdades na renda e na riqueza, assim como diferenças na autoridade e nos graus de responsabilidade que atuam para meIhorar a condição de todos, em relação ao ponto de referência da igualdade, por que não permiti-las?". Desse raciocínio, Rawls deriva o chamado de princípio da diferença, segundo o qual as desigualdades em riqueza são admitidas, desde que sob condições de iguais oportunidades e com maior benefício aos menos privilegiados. (RAWLS, John. Uma teoria da justiça. Tradução de Altamiro Piseta e Lenita M. R. Esteves. São Paulo: 'Martins Fontes, 2000c, p.64 e 163).

58 Nesta referida obra, o autor retrata um jogador russo nos cassinos de uma estação alemã. Através do personagem Aleksiéi Ivanôvitch, é corporificada a paixão pelo jogo, pela roleta, pelo ganho e pela perda. O personagem narrador também é apaixonado por Polina Aleksandrovna e persiste, em toda a trama, em contar com a sorte, seja no jogo, seja no amor (talvez mais naquele do que neste). 
abrangentes de conduta moral, exclui e desconsidera membros que professem outras doutrinas.

Pelos dois motivos expostos, o jogador não é considerado como parte na posição original. O jogador não seria capaz de assumir termos equitativos de cooperação social e, muito menos, de estabelecer uma concepção de justiça racional, no sentido rawlsiano. Se o jogador busca ganhar, certamente a posição do outro será a de perdedor, suprimindo a ideia de racionalidade mutuamente desinteressada.

Entretanto, a concepção moral de Rawls a respeito do jogador ignora o fato de que a equidade lhe é indiferente. Na verdade, ao jogador tudo aquilo que não represente ganho é enfadonho e irrelevante. $O$ jogador efetivamente como Rawls definiu ser unicamente motivado pelo ganho próprio, sendo que termos equitativos Ihes são indiferentes, como resultado do jogo. Mas isso não o faz desprovido de racionalidade: somente sua razão não está comprometida com os objetivos e conteúdos da concepção política de justiça.

A racionalidade do jogador é voltada para o cumprimento das regras do jogo e para a conquista da sorte. Sem isso, não há que se falar em jogo. Seguindo as regras, o jogador consegue estipular a tática adequada a fim de satisfazer seu objetivo de ganho. Assim, tendo um objetivo (a vitória), o jogador consegue orientar suas práticas para a realização do seu projeto ${ }^{59}$. 0 jogador não é um ser irracional ou incivilizado - antes é cumpridor das regras e almeja o ganho.

Ou seja, se a racionalidade é a capacidade de escolher um projeto de vida e tomar decisões em prol de sua realização, o jogador é um ser racional. Entretanto, sua exclusão como parte na posição original é mantida, por não estar disposto a estabelecer termos equitativos de cooperação social. E por isso, a formulação da concepção política de justiça não pode ser equiparada a um jogo.

59 "Certo dia, por exemplo, à tardinha, sucede que o negro alterna sem cessar com vermeIho; de formas que cada uma das duas cores saía apenas duas ou três vezes a seguir. No entanto, naquela mesma manhã ou à noite, vermelho dá em todos os golpes, suponhamos vinte e duas vezes seguidas, e isso continua assim infalivelmente durante algum tempo, às vezes durante o dia inteiro. Algumas dessas observações me foram passadas por Mr. Astley que passa todo o dia grudado ao pano verde, embora sem jogar uma vez sequer. Quanto a mim, perdi hoje todos os meus recursos pecuniários em curtíssimo espaço de tempo." (DOSTOIÉVSKI, Fiodor. Um jogador. Tradução de Boris Schnaiderman. 2. ed. São Paulo: Editora 34, 2004, p. 42) 
O problema é que, para Rawls, os termos equitativos de cooperação social devem necessariamente conduzir a um sentimento de benevolência. Esse sentimento, mesmo diante da racionalidade mutuamente desinteressada, faz com que seja considerada relevante a condição do menos favorecido. Aliás, nem mesmo essa condição é aceitável, segundo os princípios de justiça.

Justamente, o centro da questão está aí. O jogador consegue cumprir regras e com os termos equitativos de cooperação, pois aceita que as regras do jogo serão iguais para todos os jogadores. Entretanto, em nada a equidade de regras pode garantir a igualdade ao fim do jogo. Haverá um vencedor e um perdedor, e todos se submetem às mesmas regras. Esse é o sentido cooperativo, que na justiça equitativa precisa de maiores exigências morais das partes.

A indiferença do jogador em relação à equidade não evidencia que lhe seja contrário e muito menos que seja irracional. Simplesmente, não há sentido no resultado do jogo equitativo. Porque, em primeiro lugar, não é viável prever resultados dos jogos. Por maior que seja a técnica do jogador, este necessita contar com a sorte. E depois, porque, mesmo que previsto ou previsível o resultado do jogo, este não tem sentido se for equitativo - a menos em situações de empate. Então, o único sentido de equidade seria no estabelecimento de regras do jogo, em que as partes devem ser igualmente consideradas. Mas nenhuma regra assegura a equidade de resultados.

O jogador é aquele que tudo aposta sem segurança do resultado - aposta na sorte. Seu prazer é o ganho, mas a aposta também lhe faz sentir algo novo, sentir-se vivo e podendo ganhar. Tanto assim é que, mesmo diante da derrota, o jogador não desiste. E não desiste porque deseja participar do jogo. Essa é a figura do jogador descrita em Um jogador, de Dostoievski60.

Ou seja, seguir as regras do jogo na possibilidade de ganho, sem segurança quanto ao resultado final, é a atitude racional do jogador. Ora, somente se não houvesse desvios entre as regras e o resultado é que se poderia acreditar em regras que conduzem a resultados previstos. Entretanto, seguir as regras é a 60 DOSTOIÉVSKI, Fiodor. Um jogador. Tradução de Boris Schnaiderman. 2. ed. São Paulo: Editora 34, 2004. 
única garantia de equidade que se tem. Mesmo seguindo regras, não é possível assegurar que, a partir da aplicação de certas regras e princípios se obterão resultados equitativos ${ }^{61}$.

O jogador é aquele que não se enquadraria no padrão de racionalidade liberal da justiça equitativa, pois não tem por objetivo um resultado equitativo. É claro que todo o membro de uma sociedade democrática constitucional, para Rawls, é livre para determinar sua concepção de bem. E alguém pode achar que o bem é ganhar a vida por meio do jogo ${ }^{62}$. No entanto, não seria racional despender até seus últimos recursos no jogo, pois não há certeza de um ganho que possa assegurar ojogador - e muito menos que possa assegurar resultados equitativos. $E$ mais, o jogador, ao vencer, desejando tudo para si, é indiferente à sorte alheia ${ }^{63}$.

Por isso, há dois problemas com a concepção política de pessoa em John Rawls. O primeiro deles, o fato de que a exclusão da noção de jogo e do jogador da posição original é suficientemente apressada. Isso porque o jogador é um ser racional e disposto a termos equitativos de cooperação social, pois cumpre 61 "Certo dia, por exemplo, à tardinha, sucede que o negro alterna sem cessar com vermeIho; de formas que cada uma das duas cores saia apenas duas ou três vezes a seguir. No entanto, naquela mesma manhã ou à noite, vermelho dá em todos os golpes, suponhamos vinte e duas vezes seguidas, e isso continua assim infalivelmente durante algum tempo, às vezes durante o dia inteiro. Algumas dessas observações me foram passadas por Mr. Astley que passa todo o dia grudado ao pano verde, embora sem jogar uma vez sequer. Quanto a mim, perdi hoje todos os meus recursos pecuniários em curtíssimo espaço de tempo." (DOSTOIÉVSKI, Fiodor. Um jogador. Tradução de Boris Schnaiderman. 2.ed. São Paulo: Editora 34, 2004. p. 42).

62 O narrador, nesta cena, é enfático em negar-se a jogar por Polina - acredita que jogar por outra pessoa lhe consome sua sorte. Acredita sinceramente que o jogo é a sua forma de vida: "Subindo para o meu quarto, pude entregar a Polina o seu ganho e declarei-Ihe que não ia mais jogar para ela. - Mas por quê? - perguntou, sobressaltada. - Porque quero jogar para mim mesmo - respondi, examinando-a surpreendido - e isso atrapalha. - Então, continua firmemente convicto de que a roleta é a sua única saída e salvação? - Perguntou com sarcasmo. Respondi, muito seriamente, que sim; e, quanto à minha convicção de ganhar infalivelmente, eu estava de acordo em que podia ser ridícula, mas que "me deixasse em paz". (DOSTOIÉVSKI, Fiodor. Um jogador. Tradução de Boris Schnaiderman. 2. ed. São Paulo: Editora 34, 2004, p. 27)

63 O relato final do livro é bem ilustrativo: Perdera então tudo, absolutamente tudo... Ao sair do cassino, remexendo no bolso achei um florim. "Ora, viva! Tenho com que jantar!", disse com os meus botões; mas, após ter dado cem passos, mudei de opinião e voltei ao cassino. Pusesse florim em manque (era a vez de manque). Na verdade, sente-se uma indizível sensação quando, sozinho em terra estranha, longe de amigos e da pátria, e sem saber se se terá o eu comer nesse dia, se arrisca o último florim. O último florim! Ganhei; vinte minutos mais tarde, ao me retirar do cassino, possuía cento e setenta florins! Aí está o fato do que significa às vezes o último florim! Se, nesse dia, tivesse perdido a coragem, se não tivesse tido a ousadia de tomar tal decisão? (DOSTOIÉVSKI, Fiodor. Um jogador. Tradução de Boris Schnaiderman. 2. ed. São Paulo: Editora 34, 2004. p.215) 
as regras. E o segundo problema está em pressupor que termos equitativos de cooperação social assegurem um resultado equitativo, ou comprometido com algum ideal de justiça na distribuição dos bens.

Talvez não seja um problema defender um ideal de justiça equitativa. $O$ problema é concebê-lo como uma perspectiva autossustentável, que não busca fundamento em nenhuma doutrina abrangente. $O$ fato é que a formulação dos princípios de justiça, em especial, do princípio da diferença, só pode ocorrer com base em uma subjetividade determinada por doutrinas abrangentes condizentes, e não somente racionais.

\section{CONSIDERAÇÕES FINAIS}

A autossustentabilidade da justiça equitativa rawlsiana é ameaçada por sua dependência em relação a uma concepção política de pessoa com bases metafísicas. Isso porque a concepção política de pessoa foi alicerçada em uma moral abrangente. Embora declaradamente Rawls pretendesse a independência de sua concepção de pessoa em relação a padrões morais, definindo-a como racional, o que ocorre é o surgimento de uma noção abrangente de pessoa. E por isso, excludente. A exclusão se verifica na medida em que comportamentos racionais não são considerados na posição original. Um exemplo disso é o jogador.

O jogador é excluído da posição original por, supostamente, não aceitar termos equitativos de cooperação social. E tal se depreende do fato de que o jogador age exclusivamente em função de seu próprio ganho. Se assim for, o jogador prevê, na distribuição dos bens primários, posição desfavorecida (a do perdedor). Por esse fato, o jogador não seria um membro disposto aos termos equitativos que devem predominar sob uma concepção política de justiça.

O problema está na própria ideia de termos equitativos de cooperação. Se estes sejam tais que garantam um resultado equitativo, realmente o jogador não é capaz de aceitá-los. Entretanto, se os termos equitativos forem considerados aqueles que preservam a igual consideração entre os membros, então a estrutura de jogo corresponde à posição original. Por aí, o argumento de Rawls se dissolve. 
E mais: o fato de o jogo resultar em desigualdade de partes ao final da partida não faz da regra do jogo um termo desequilibrado de cooperação social - o jogo é indiferente à ideia de equilíbrio. Por isso, não há sentido na afirmação que Rawls faz na tentativa de eliminar a ideia de jogo da posição original.

No entanto, o autor desconsidera o problema do jogo e do jogador em confronto com uma concepção de pessoa política racional. A racionalidade serve como um argumento excludente político, sendo, de fato, um argumento moral. Se tal fato for considerado, tem-se o compromisso da justiça como equidade com padrões metafísicos e, portanto, sem a autossustentabilidade pretendida por seu autor. Nesse sentido, a teoria da justiça é avessa ao debate político, visto que formulada sobre fundamentos morais abrangentes.

\section{REFERÊNCIAS}

DOSTOIÉVSKI, Fiodor. Um jogador. Tradução de Boris Schnaiderman. 2. ed. São Paulo: Editora 34, 2004.

FELIPE, Sônia T. A concepção política de justiça em John Rawls. In: Sequência. Florianópolis: Curso de Pós-Graduação em Direito UFSC, ano 17, n. ${ }^{\circ} 33$.

KRISCHKE, Paulo J. A cultura política pública em John Rawls: contribuições e desafios à democratização. IN: FELIPE, Sônia (org). Anais do simpósio internacional sobre a justiça. Florianópolis: Insular, 1998.

RAWLS, John. Justiça e democracia. Tradução de Irene A Paternot. São Paulo: Martins Fontes, 2000a.

RAWLS, John. O Liberalismo Político. Tradução de Dinah de Abreu Azevedo. 2. ed. São Paulo: Ática, 2000.

RAWLS, John. Uma teoria da justiça. Tradução de Altamiro Piseta e Lenita M. R. Esteves. São Paulo: Martins Fontes, 2000.

SILVA, Vera Lucia da (2005). Política e tragédia: os arquétipos da exclusão no liberalismo rawlsiano. Dissertação de mestrado. Curso de Pós-Graduação em Direito da Universidade Federal de Santa Catarina. Disponível em: http://aspro02.npd.ufsc.br/arquivos/220000/22240 0/18_222439.htm. Acesso em: 11/09/2015. 
VITA, Álvaro de. A justiça igualitária e seus críticos. São Paulo: Martins Fontes, 2007.

VITA, Álvaro de. Duas interpretações da motivação moral. In: FELIPE, Sônia (Org). Anais do simpósio internacional sobre a justiça. Florianópolis: Insular, 1998.

Recebido em: jan/2016 Aprovado: nov/2016 